\title{
Analysis of Resource Use Efficiency of Low Land Rice Production in Katcha Local Government Area of Niger State
}

\author{
Dauda, $\mathrm{S} \mathrm{N}^{1}$ Tiamiyu S A1 Ibrahim $\mathrm{ST}^{2}$ \\ ${ }^{1}$ National Cereals Research Institute, Badeggi P M B 8, Bida Niger State \\ ${ }^{2}$ Department of Agricultural Economics and Extension, Federal University of Technology Minna Nigeria
}

\begin{abstract}
: this research was carried out to study the resource use efficiency of low land rice production in Katcha Local Government Area of Niger State. The specific objectives were to determine the resource use efficiency, describe socio-economic characteristic of low land rice farmers and problems faced by low land rice farmers in study area. Two districts were purposively selected out of which ten villages were randomly selected.And random sampling proportional to size of each village was used to select 200 rice farmers using 1991 census figure. Descriptive statistics was used to examine socio-economic characteristic and production experience of rice farmers. Production function analysis was used to determined resource use efficiencyin low land rice production of the farmers. The result of descriptive statistic indicated that $86.5 \%$ of low land rice farmers were between the ages of 20 -50 years. Majority of the farmers were literate with long experience of rice cultivation. The MV P/M F C ratio of resources like farm size, seed material, Agro chemical and fertilizer were underutilized because their ratio were greater than 1 while family and hired labor ratio of MVP/MFC shows over utilization because their ratio were less than 0 which means all resources were inefficiently utilized. The best fit analysis which is lead equation was semi log with $F$-value of 94.831, and $R^{2}$ of 0.747 . Farm size seed materials and fertilizer were significant at $1 \%$ level of probability. The elasticity of production was 0.724 indicating decreasing return to scale. It was recommended that the use of farm size, seed rate, agro chemical and fertilizer be increased while the use of family and hired labor should be reduced.
\end{abstract}

Key words: low land rice, resource use efficiency, small scale production and Niger state.

\section{Introduction}

Agriculture supplies food, raw materials and generates house hold income for the majority of the people, contributes less than 5\% to the G.D.P. and trade imports are dominated by capital foods, raw materials and food (Akande, 2002). Nigeria is currently preoccupied with the challenge of diversifying the structure of its economy, food sub-sector of Nigeria agriculture parades a large array of staple crops made possible by the diversity of agro-ecological production systems (Akande, 2002).

Rice is the world most expensively cultivated crop and forms the staple food for over $50 \%$ of the world population (NCRI, 2008). Rice is one of major food crop commodity that is of considerable importance for food security, expenditures and incomes of households, the demand for rice been increasing at a much faster rate in Nigeria than in other West African countries (Akande, 2002). According to RIFAN (2006), Nigeria with the population of over 140 million people, has a variety of factors that favor rice production. National cereal Research Institute, through RIFAN has revealed that, Nigeria has approximately 5 million hectares of land suited for rice production. However, despites the large expanse of land for production of rice in Nigeria per capita consumption is very low, because Nigeria needs 5 million metric tons of milled rice per year and production was estimated to be about 3 million metric tons of milled rice leaving a short fall of 2 million metric tons which is augmented by importation (RIFAN, 2006).

According to FAO (2002) statistics, self-sufficiency rating for rice was $84 \%$ in 1998 and 2 million metric tons importation out of 5 million metric tons was estimated to cost about 300 million U.S dollars, this dampens the hope of possible improvement in the level of domestic rice production. In addition, the central bank of Nigeria informed participants at a RIFAN/CBN organized seminar that 578 million U.S dollars' worth of rice was imported in 2002 (RIFAN, 2006). The demand for rice in Nigeria is partly the result of increasing population growth, increased income levels, rapid urbanization and associated changes in family occupational structure, hence, an average Nigeria now consumes $24.8 \mathrm{~kg}$ of rice per year (Akande, 2002).

Certainly, rice has been a good partner to humankind, and adaptive ecological, economical and technological changes, around rice facilitated this 'partnership between man and rice ' for instance in terms of rapid population growth, soaring rice demand were not largely due to the increase in rice production. As such, we must continue to nature this partnership added(Braun, 2006) Nigeria's estimated annual rice demand is put at 5 million metric tons while it produces on the average about 2.21 million product leaving a deficit of 2.29 million tons which is bridged by importation, National Rice Development Strategy(NRDS). Domestic demand 
for rice is projected to rise to 7.5 million tons by 2013 ,on the assumption that demand rises at the level of $10 \%$ per annum ,with demand for local rice growing at half the rate of imported rice added(NRDS,2009).

Achieving sustainable economic development in Nigeria will confront three central challenges; alleviating wide spread poverty, meeting current and future food needs and efficiently using the natural resources base to ensure sustainability (Daramola, 2005). The Nigeria rice industry is currently not competitive because it faces the following constraints: macroeconomic conditions under which Nigeria rice is produce is partly responsible for the sector's lack of competitiveness, high cost of inputs, problem of policy instability (Daramola, 2005).

Considering the risk and uncertainty in which agricultural production takes place most especially in developing countries, farmer's resources need to be organized and used efficiently in such a way as to produce maximum output (Yahaya, 2007). The global price of rice has increased by over 100\% in 2008 alone, that coupled with the fact that other food items and goods, such as oil have been increased sharply does little to give piece of mind to consumers (free online article Directory, 2009). The resources use efficiency measures will go on a long way to show possible areas of adjustments that need to be made by the rice producers in the study area. In view of these, it is relevant to assess the efficiency of resource use in the production of rice in the study area; because inadequate explanation on the level of resource use may lead to over or under utilization of farm resources and the effect of this may be reflected on the profitability.

Considering the above, the following objectives were formulated for the study:describe the socioeconomic characteristics of the respondents;determine the resource use efficiency of low land rice production in the study area and identify the major problems faced in the production of rice in the study area.

\section{Methodology}

The study was carried out in Katcha Local government area of Niger state, Nigeria. The study area is well known for rice production especially Badeggi. The demand for this crop in the study area is increasing because of its importance as a source of food and income. The mean temperature is $29.15^{\circ} \mathrm{C}$ with the latitude of $8^{0}-10^{0}$ North and longitude of $3^{0}-8^{0}$ East. The study area enjoys tropical climate with two distinct seasons. These are rainy (April to October) and dry (November to March) seasons with an annual rainfall of between 1000mm $-1200 \mathrm{~mm}$ (Misari, 2002). The Local Government was purposively selected because of the preponderance of rice farmers in the area.For this studytwo districts were purposively selected from 8 districts of the local government area because of their proximity to Gbako River where they practice low land rice cultivation and hence high concentration of low land rice farmers in the area. The selected districts are Badeggi and Sidisaba.Simple random sampling technique was used to select five villages from each of the selected districts. A total of 200 low land rice farmers were randomly selected based on the proportional size of low land rice farmers in each selected village. Primary data were collected during a field survey. Primary data for the study was collected with aid of well-structured questionnaires. The information obtained include: socio-economic characteristics, number of plots owned, quantity of herbicides used in liters, quantity of fertilizer used in kilogram, farm tools used. Others include seeds planted, farming operations and returns from the rice farm.Descriptive statistics and production model were used to determine socio economic characteristics and resource use efficiency of low land rice. The four functional forms of the production model are specified in their explicit form as follows;

The linear model

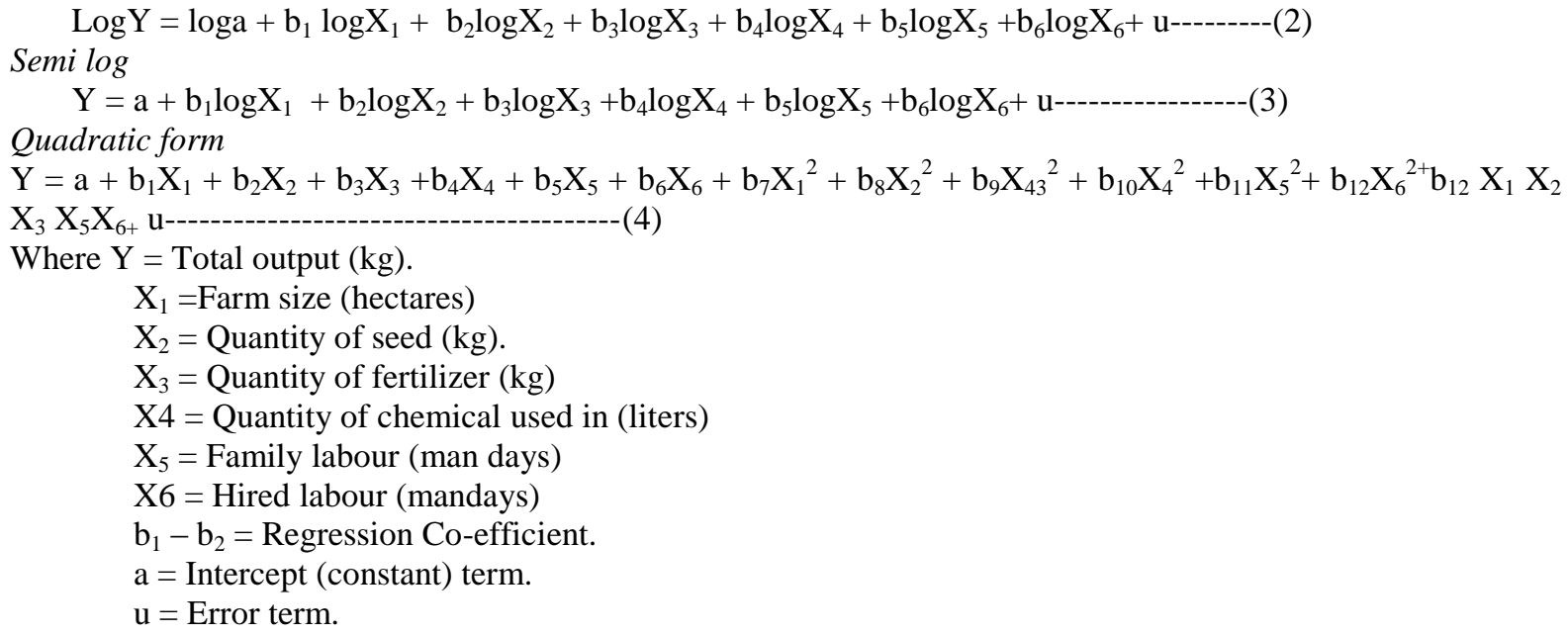


In order to find the efficiency of resource utilization, the Marginal Value Productivity (MVP) of each input was calculated by using the regression coefficient of each input and geometric mean value of farm revenues and farm inputs. The Marginal Factor Cost (MFC) of input was taken to be the market price of farm inputs. The ratio of the MVP to MFC of each input was calculated to measure the resource use efficiency.

The rules are:

When $\mathrm{r}<1$, the resources are over utilized and reducing the used of those resource will increase the profit.

When $r>1$, the resources are underutilized, increasing the quantity of those resources will increase the output and hence the profit.

When $r=1$ it indicates efficient utilization of resources.

\section{Results and Discussion}

Table 1: Socio-economic characteristics of respondents $(n=200)$

\begin{tabular}{|c|c|c|}
\hline Age (Years) & Frequency & Percentage \\
\hline $21-30$ & 70 & 35 \\
\hline $31-40$ & 54 & 27 \\
\hline $41-50$ & 49 & 24.5 \\
\hline Above 50 & 27 & 13.5 \\
\hline Education acquired & & \\
\hline Qur'an & 105 & 52.5 \\
\hline Western education & 9 & 4.5 \\
\hline Qur'an and western & 86 & 43 \\
\hline Farming experience (Years) & & \\
\hline$<10$ & 27 & 13.5 \\
\hline $11-20$ & 95 & 47.5 \\
\hline $21-30$ & 69 & 34.5 \\
\hline Above 31 & 9 & 4.5 \\
\hline Number of farm plots (hectares) & & \\
\hline$<0.5-1$ & 78 & 39 \\
\hline $1-2$ & 79 & 39.5 \\
\hline $2-3$ & 43 & 21.5 \\
\hline
\end{tabular}

SOURCE: field survey 2010

Age plays an important role in the farming activities as it determines the effectiveness and competence of labor availability for rice production. The result in Table 1 shows that Majority $(86.5 \%)$ of the respondents were within the prime age group of 21- 50 years. this implies that, rice cultivation is done by young adult farmers within this age bracket. This agrees with the findings of Adeola, et al (2008) and Sani et al (2010) who said $76.67 \%$ are within the age bracket of 30-49years of age.This is because these categories of farmers are still strong, have the ability to supply the require labor in agricultural activities to boost production and also increase resource use efficiency.The result on Table 1 further revealed that all the farmers are literate in one way or the other. This could lead to increase in awareness and adoption of rice production technology and better standard of living of the farmers in the study area. This is because literate individual accept new technique easily and manage better than illiterates. The result in Table 1 also shows that majority (86.5\%) of the respondents in the study area had cultivation experience of 11 years and above. The years of farming experience in low land rice cultivation is expected to increase individuals' experience of better farm management practices and resource use efficiency there by reducing the cost and increasing the output. The Table also revealed that $39 \%$ and $39.9 \%$ of the respondents respectively have $0.5-1$ and 1-2 hectaresof low rice farm land while only $21.5 \%$ of the respondents have 2-3hectares of rice farm land. Thesmall, fragmented and scattered plots of the farm lands may be explained by the method of land acquisition which is through inheritance. The mode of low land rice farm land acquisition is through inheritance indicating scattered and fragmented farm plots here and there. This study also agrees with Alimi (2001) who from his clear studies revealed that land acquisition through inheritance still remains a popular mode in Nigeria because he obtained $85 \%$ respondents as his result.

Table 2: Result of semi- log regression model for low land rice production in the study area.

\begin{tabular}{|l|l|l|}
\hline Variables & Regression coefficient & T-value \\
\hline Farm size $\left(\mathrm{X}_{1}\right)$ & 1859.851 & $3.568^{* * *}$ \\
Seed $\left(\mathrm{X}_{2}\right)$ & 1116.918 & $3.563^{* * *}$ \\
Fertilizer $\left(\mathrm{X}_{3}\right)$ & 582.497 & $2.743^{* * *}$ \\
Agro chemical $\left(\mathrm{X}_{4}\right)$ & 342.853 & $0.679 * *$ \\
Family labor $\left(\mathrm{X}_{5}\right)$ & -158.846 & $-0.449^{\mathrm{ns}}$ \\
Hired labor $\left(\mathrm{X}_{6}\right)$ & -83.607 & $-.520^{\mathrm{ns}}$ \\
\hline
\end{tabular}

${ }_{\mathrm{R}} 2=0.747$

Source Field Survey, 2010

***significant at $1 \%$ level of probability

$* *$ significant at $5 \%$ level of probability 
Ns=not significant.

Input- output Relationship

The result of semi $\log$ production function shows that, the value of $\mathrm{R}^{2}$ is 0.747 . This mean that $75 \%$ of the total variation in the dependent variable is explained by variation in the independent variable included in the model showing that only $25 \%$ of output is as a result of error. The regression co-efficient of farm size, seed, fertilizer and agro chemical are positive meaning that unit increase in any of those variables holding others constant will increase the output. Family and hired labor are negative indicating decrease in output holding others constant

T-value of each of these variableswere the contribution of each, for instance a unit increase of farm size $\left(\mathrm{x}_{1}\right)$ will increase the output by $3.56 \mathrm{~kg}$ of paddy rice.The $\mathrm{T}$ - value of family and hired labor are negative, meaning that a unit increase in family labor will decrease the output by 0.449

Resource Use efficiency; theestimated co-efficient of the independent variables were used to computes the marginal value product (MVP) and their marginal factor cost (MFC). The ratio of MVP to MFC used to find the resource used efficiency as shown below

1. Table 3: Estimated efficiency ratio of low land rice production in the study area.

\begin{tabular}{|l|c|c|c|c|}
\hline Variables & MPP & MVP & MFC & Efficiency ratio $(\mathrm{r})$ \\
\hline Farm size $\left(\mathrm{X}_{1}\right)$ & 534.286 & 2014.4 & 1700 & 1.18 \\
Seed $\left(\mathrm{X}_{2}\right)$ & 5.06 & 2155.507 & 384.5 & 5.606 \\
Fertilizer $\left(\mathrm{X}_{3}\right)$ & 1.089 & 1851.3 & 1700 & 1.089 \\
Agro chemical $\left(\mathrm{X}_{4}\right)$ & 51.71 & 51710 & 1000 & 51.712 \\
Family labor $\left(\mathrm{X}_{5}\right)$ & -3.197 & -1598.5 & 500 & -3.197 \\
Higher labor $\left(\mathrm{X}_{6}\right)$ & -4.153 & -0276.5 & 500 & -4.153 \\
\hline
\end{tabular}

Source field survey, 2010

The table shows that the ratio of MVP to MFC indicates resulting ratio to be more than unity for farm size, seed, fertilizer, and agro chemical. This mean that a unit increase in each input would increases the value of output, meaning that all these inputs are underutilized. This agrees with the work of Sani et al (2010) that did the work on Resource use efficiency in rice production under small scale irrigation in Bunkure Local Government Areaof Kano State. The result says that all the seed, fertilizer land and labor were underutilized. The seed, fertilizer and agro chemical may be due to costly nature of the inputs. The farm size was due to inheritance while family and hired labor were due to free nature and jinga respectively. The marginal value product of size of farm is N908286.2 divided by the total number of hectares of sampled farmers which is equal N2014.4/ha based on the print out and calculation of MVP. This means that an increase by 1 hectare will increase the total product byN2014.4.

Table 4: Estimated elasticity of inputs and return to scale

\begin{tabular}{|l|c|}
\hline Variable & Coefficient of elasticity of production \\
\hline Farm size $\left(\mathrm{X}_{1}\right)$ & .450 \\
Seed $\left(\mathrm{X}_{2}\right)$ & .262 \\
Fertilizer $\left(\mathrm{X}_{3}\right)$ & .156 \\
Agro chemical $\left(\mathrm{X}_{4}\right)$ & .091 \\
Family labor $\left(\mathrm{X}_{5}\right)$ & -.025 \\
Hired labor $\left(\mathrm{X}_{6}\right)$ & -.21 \\
\hline Return to scale & 0.724 \\
\hline
\end{tabular}

Sources field survey, 2010.

The elasticity of production(e p) of all the inputs calculated together gives 0.724 showing decreasing return to scale meaning that if these resources are increase by $1 \%$, the output will be increased by less than a $\%$. Works of Sani etal (2010) and Amaza et al (1999) gave efficiencies of 0.815 and 0.69 respectively. The study shows that production is characterized by a decreasing return to scale. The production is increasing at decreasing rate meaning that output does not justify increment in explanatory variable.

The problems are both climatic and biotic influence.

*The frequency added to more than 200 as result of multiple responses 
Table 5: Distribution of respondents based on the challenges faced in production Challenges face in the production

\begin{tabular}{|l|c|c|}
\hline Problem & Frequency* & Percentage \\
\hline Qualia birds attack & $90^{*}$ & 26.70 \\
Flooding of farm land & $120^{*}$ & 35.20 \\
High cost of fertilizer & $60^{*}$ & 17.60 \\
High cost of agro chemical & $70^{*}$ & 20.50 \\
\hline Total & $340^{*}$ & 100 \\
\hline
\end{tabular}

Source field survey, 2010

$*=$ multiple responses

The analysis of the challenges encountered by most of the low land farmers are more of climatic and biotic influences. This include heavy flood that washed the whole farm land and the planted rice seeds. Biotic influence includes qualia birds that cause a lot damages to rice at milking stage leading to low yield. The table revealed that low land rice farmers in the study area (35.2\%) are faced with the problem of flooding. There was also financial constrains faced by the farmers, together with the high cost of fertilizer and Agro chemical which are very vital in the production of low land rice.

\section{Conclusion}

Production resources of low land rice farmers in study area were not efficiently utilized as shown above from the MVP/MFC ratio. This will show possible areas of adjustment that need to be made by rice producers. Knowledge of resource use efficiency adjustment may be useful to those who might want to invest but have little or no information of the business. It is put forward that inputs like fertilizer, seed and agro chemical should be made available. The result could be used by government to assist the rice producers on credit and subsidy bases by providing themwith production resources.

\section{References}

[1]. Alimi, T (2001) "Resource use efficiency in food crop production in Oyo state of Nigeria, journal of Agriculture and Environment, $1(1) ; 1-7$.

[2]. Amaza P.S and J.K Olayemi (1999). An investigation of technical efficiency of production of farmerunder the National Directorate of Employment in Ondo State.

[3]. Applied Economics Letters, Rout ledge, 6: 11 -114

[4]. Akade T. (2002)an overview of Nigerian Rice Economy.

[5]. Adeola, R G..., O.O. Adebayor and G.O. Oyelere (2008).Effects of the Federal Government

[6]. Special rice programs me on rice yield and farmers income in Oyo State.

[7]. Braum,JV.,(2006); public policy and international collaboration for sustainable and expanding therice revolution A key note at the $2^{\text {nd }}$ international rice congress on 'science technology and trade for peace and prosperity; International food policy Research Institute (IFPRI) Washington D. C. USA.

[8]. Daramola, B. (2005) Government Policies and Competitiveness of Nigerian Rice Economy,Food security in sub-Sahara Africa.

[9]. 'Food and Agriculture Organization (2002) "Rice Information Volume2" January 2002.Free Online Article Directorate. (2009) [Online] Retrieved from 2009 April. Available from file: // F Rice: rice \% 20c.htm.

[10]. Misari. S. (2002):"'Rice Research Programme Report in Annual Review Meeting"' 25 -28 June. National Cereal Research Institute Badeggi (2008): Training manual on and processing PP15 -18.

[11]. Rice Farmers Association of Nigeria (RIFAN 2006):Retrieved from "http:/mistowa.org/filecorpao/20064 Rifan" on $3^{\text {rd }}$ march, 2008.

[12]. Sani A, A.A Yakubu and H.M. Bello (2010) Resource Use Efficiency in Rice Production underSmall Scale Irrigation in Bunkere Local Government Area of Kano state.

[13]. National Rice Development Strategy (NRDS) (2009); a working Document prepared for the Coalition for African Rice Development may 2009. 